University of Nebraska - Lincoln

DigitalCommons@University of Nebraska - Lincoln

Biochemistry -- Faculty Publications

Biochemistry, Department of

2009

Polyploidy creates higher diversity among Cynodon accessions as assessed by molecular markers

Osman Gulsen

Erciyes University, Melikgazi, Turkey, o_gulsen@yahoo.com

Songul Sever-Mutlu

University of Nebraska-Lincoln, severmutlu@hotmail.com

Nedim Mutlu

University of Nebraska - Lincoln, nmutlu2@unl.edu

Metin Tuna

Namik Kemal University, Tekirdag, Turkey

Osman Karaguzel

Akdeniz University, Antalya, Turkey

See next page for additional authors

Follow this and additional works at: https://digitalcommons.unl.edu/biochemfacpub

Part of the Biochemistry, Biophysics, and Structural Biology Commons

Gulsen, Osman; Sever-Mutlu, Songul; Mutlu, Nedim; Tuna, Metin; Karaguzel, Osman; Shearman, Robert C.; Riordan, Terrance P.; and Heng-Moss, Tiffany M., "Polyploidy creates higher diversity among Cynodon accessions as assessed by molecular markers" (2009). Biochemistry -- Faculty Publications. 92.

https://digitalcommons.unl.edu/biochemfacpub/92

This Article is brought to you for free and open access by the Biochemistry, Department of at DigitalCommons@University of Nebraska - Lincoln. It has been accepted for inclusion in Biochemistry -- Faculty Publications by an authorized administrator of DigitalCommons@University of Nebraska - Lincoln. 


\section{Authors}

Osman Gulsen, Songul Sever-Mutlu, Nedim Mutlu, Metin Tuna, Osman Karaguzel, Robert C. Shearman, Terrance P. Riordan, and Tiffany M. Heng-Moss 
Published in Theoretical and Applied Genetics: International Journal of Plant Breeding Research 118 (2009), pp. 1309-1319; doi: 10.1007/s00122-009-0982-9 Copyright (c) 2009 Springer-Verlag. Used by permission.

Submitted October 30, 2008; accepted January 31, 2009; published online February 20, 2009.

\title{
Polyploidy creates higher diversity among Cynodon accessions as assessed by molecular markers
}

\author{
Osman Gulsen, ${ }^{1}$ Songul Sever-Mutlu, ${ }^{2}$ Nedim Mutlu, ${ }^{3}$ Metin Tuna, ${ }^{4}$ Osman Karaguzel, ${ }^{5}$ \\ Robert C. Shearman, ${ }^{2}$ Terrance P. Riordan, ${ }^{2}$ and Tiffany M. Heng-Moss ${ }^{6}$ \\ 1. Department of Horticulture, Faculty of Agriculture, Erciyes University, Melikgazi, 38039 Kayseri, Turkey \\ 2. Department of Agronomy and Horticulture, University of Nebraska-Lincoln, Lincoln, NE 68583, USA \\ 3. Department of Biochemistry, University of Nebraska-Lincoln, Lincoln, NE 68588, USA \\ 4. Department of Field Crops, Namik Kemal University, 59030 Tekirdag, Turkey \\ 5. Department of Landscape Architecture, Akdeniz University, 07070 Antalya, Turkey \\ 6. Department of Entomology, University of Nebraska-Lincoln, Lincoln, NE 68583, USA \\ O. Gulsen and S. Sever-Mutlu contributed equally to this work, and are considered co-first authors. \\ Corresponding author - Osman Gulsen, email o_gulsen@yahoo.com
}

\begin{abstract}
Developing a better understanding of associations among ploidy level, geographic distribution, and genetic diversity of Cynodon accessions could be beneficial to bermudagrass breeding programs, and would enhance our understanding of the evolutionary biology of this warm season grass species. This study was initiated to: (1) determine ploidy analysis of Cynodon accessions collected from Turkey, (2) investigate associations between ploidy level and diversity, (3) determine whether geographic and ploidy distribution are related to nuclear genome variation, and (4) correlate among four nuclear molecular marker systems for Cynodon accessions' genetic analyses. One hundred and eighty-two Cynodon accessions collected in Turkey from an area south of the Taurus Mountains along the Mediterranean cost and ten known genotypes were genotyped using sequence related amplified polymorphism (SRAP), peroxidase gene polymorphism (POGP), inter-simple sequence repeat (ISSR), and random amplified polymorphic DNA (RAPD). The diploids, triploids, tetraploids, pentaploids, and hexaploids revealed by flow cytometry had a linear present band frequency of $0.36,0.47,0.49,0.52$, and 0.54 , respectively. Regression analysis explained that quadratic relationship between ploidy level and band frequency was the most explanatory $(r=0.62, P<0.001)$. The AMOVA results indicated that 91 and $94 \%$ of the total variation resided within ploidy level and provinces, respectively. The UPGMA analysis suggested that commercial bermudagrass cultivars only one-third of the available genetic variation. SRAP, POGP, ISSR, and RAPD markers differed in detecting relationships among the bermudagrass genotypes and rare alleles, suggesting more efficiency of combinatory analysis of molecular marker systems. Elucidating Cynodon accessions' genetic structure can aid to enhance breeding programs and broaden genetic base of commercial cultivars.
\end{abstract}

\section{Introduction}

The genus Cynodon L. C. Rich. is a member of the family Graminae (Poaceae), subfamily Chloridoidae, tribe Cynodonteae, and subtribe Chloridinae (Renvoize and Clayton
1992). Members of the genus are used for pasture, forage, turfgrass, soil stabilization, and remediation (Burton 1947). Their taxonomic classifications were subjected to revisions as reviewed by Taliaferro (2003). The most widely used taxonomic system is by Harlan et al. (1970), 
which included nine species and ten varieties. Members of the genus possess substantially different morphological and adaptation characteristics. It is a heterogeneous, cross-pollinated genus with self-fertility occurring at a frequency of up to $3 \%$ (Burton and Hart 1967). The genus is comprised of a morphologically indistinguishable polyploid series of diploids, triploids, tetraploids, pentaploids, and hexaploids with a base chromosome number of $x=9$ (Wu et al. 2006). Genome composition of the genus Cynodon is largely unknown. It is considered an autoploid (Zeven 1979). Intra- and inter-ploidy level crosses, except for those involving most triploid parents, can produce viable seeds (Taliaferro 2003).

Harlan and de Wet (1969) suggested that an area from West Pakistan to Turkey is the center of evolutionary activity, and there is no report on native $C$. dactylon genetic and ploidy variation representing this region. It occurs as far as $53^{\circ} \mathrm{N}$ latitude. Cynodon dactylon var. dactylon is the most widely distributed and genetically variable species in the genus. Cynodon accessions from far east including China and Korea were reported (Wu et al. 2006; Kang et al. 2007). The Chinese Cynodon accessions had high molecular marker diversity, and included triploid, tetraploid, pentaploid, and hexaploid genotypes, missing diploids. Tetraploid accessions were the most frequent.

Polyploidy, the presence of more than two chromosome sets in single individual, is widespread among the angiosperms. Leitch and Leitch (2008) discussed that polyploidization might be a major driving force behind the divergence of the angiosperms and their biodiversity. Duplicated genes caused by polyploidy retain their original function or gain new function where extra copies may become silenced. Furthermore, Dubcovsky and Dvorak (2007) suggested that genome plasticity coupled with polyploidy was a key factor in wheat' (Triticum sp.) success under domestication. In synthetic polyploids of Brassica, genome diversification was detected only after two generations of selfing (Song et al. 1995). Hence, gene diversification in polyploids may lead to increased polymorphism detected by molecular markers, like sequence related amplified polymorphism (SRAP), intersimple sequence repeat (ISSR), and random amplified polymorphic DNA (RAPD), simple-sequence repeats, and restriction fragment length polymorphism. Accordingly, Gulsen et al. (2005) and Budak et al. (2005) found higher molecular marker diversity in higher ploidy levels among buffalograsses [Buchloe dactyloides (Nutt.) Engelm.]. Plants with higher ploidy levels produced more bands in PCR amplifications, probably due to increased heterozygosity, than those with lower ploidy levels. Per- haps, this result applies to other grasses with ploidy series.

Molecular markers can be used to identify unique associations among geographic distribution, polyploidization, and agronomic traits. The PCR-based DNA markers, such as RAPD and amplified fragment length polymorphism have been used in studies of genetic diversity, relatedness, phylogeny, and in identifying offtypes in cultivars of Cynodon (Vos et al. 1995; CaetanoAnolles et al. 1995; Zhang et al. 1999; Karaca et al. 2002; Garcia et al. 2004; Wu et al. 2005). While these studies provide baseline information on the variation in diversity, ploidy level and geographical distribution, more information on relationships between polyploidy and genetic diversity is needed to clarify evolution and relationships among Cynodon accessions with ploidy series. This study was conducted to: (1) determine ploidy analysis of Cynodon accessions collected from Turkey, (2) investigate associations between ploidy level and genetic diversity, (3) determine whether geographic and ploidy distribution are related to nuclear genome variation, and (4) correlate among four nuclear molecular marker systems for Cynodon accessions' genetic analyses.

\section{Materials and methods}

\section{Plant materials}

Vegetative propagules of 182 Cynodon accessions collected as representatives from naturally occurring populations in the ruins of gardens of historical sites and undisturbed lands of Turkey were evaluated along with seeded type bermudagrass cultivars Princess 77, Riviera, SWI-1044, SWI-1045 (Contessa), NuMex Sahara, Blackjack, Mohawk, and Sultan; a diploid C. transvaalensis Burtt-Davy experimental line, and triploid hybrid (C. dactylon $\times$ C. transvaalensis) cultivar, Tifway. Term 'Cynodon accessions', instead of a specific species name (also used by Wu et al. 2006, 2007), was used for plant genotypes because the collection sites are evolutionarily active, and the samples may include genomes of different Cynodon species. The 182 accessions were collected from a region bounded by $37^{\circ} 23^{\prime} 27^{\prime \prime}$ to the north, $35^{\circ} 53^{\prime} 51^{\prime \prime}$ to the south, $27^{\circ} 18^{\prime} 42^{\prime \prime}$ to the east, and $36^{\circ} 34^{\prime} 50^{\prime \prime}$ to the west, ranging from 0 to $1,350 \mathrm{~m}$ from the sea level (Figure 1). This area covers the Mediterranean coastal region of Turkey that lies south of the Taurus Mountains. The plant genotypes were maintained in a semi-controlled glasshouse located at Alata Horticultural Research Institute, Erdemli, Mersin, Turkey. 
Figure 1. Distribution of the C. dactylon accessions collected throughout the Mediterranean coast of Turkey. Approximate borders of the six provinces (Mugla, Antalya, Mersin, Adana, Osmaniye, and Hatay) were indicated with continuous vertical line. Western types include the genotypes from Mugla and Antalya; central types were from Mersin and Adana; and the eastern consists of the genotypes from Osmaniye and Hatay

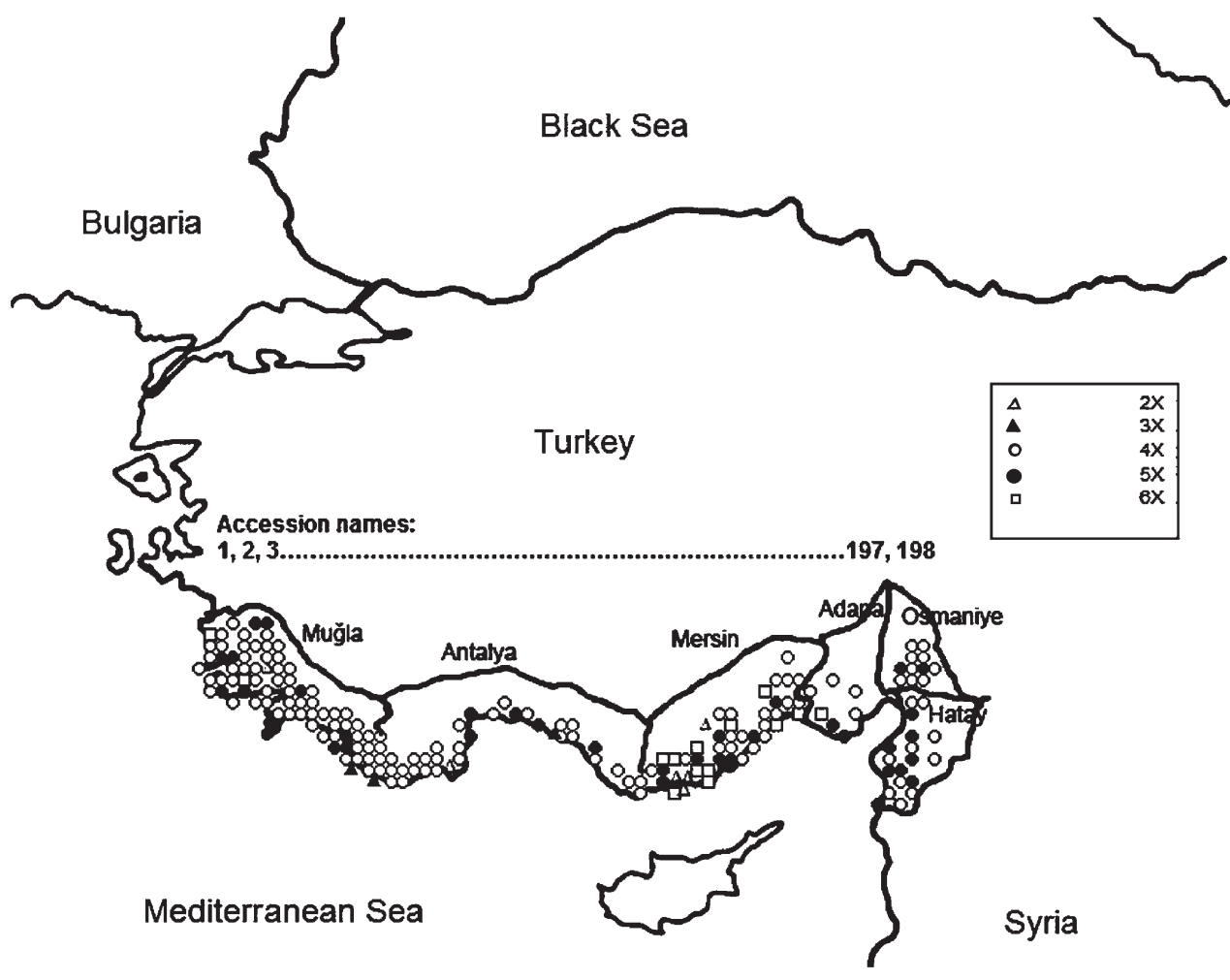

\section{Nuclear DNA content analysis}

Nuclear DNA content of each genotype was determined twice in different dates using flow cytometry (CYTOMICS FC 500, Beckman Coulter, Inc, Fullerton, CA, USA) located at the Central Laboratory of Medical School of Trakya University, Edirne, Turkey. The analysis was repeated if the CV of the sample is higher than 3. Vicia sativa L. cultivar Kara Elci and Hordeum vulgare L. cultivar Sladoran were used as internal standards in the study. After nuclear DNA content analysis, chromosome number of two or three genotypes for each DNA content level was counted and DNA contents were correlated to ploidy levels for the rest of the genotypes as described in Tuna et al. (2001).

\section{DNA isolation and analysis of molecular markers}

Single fresh leaf was harvested from each genotype and used for DNA extraction. All genotypes, including seeded cultivars, were vegetatively cloned using a single stolon from each population; therefore, samples of seeded cultivars may not represent original population. Total DNA was extracted from $100 \mathrm{mg}$ fresh leaf tissue according to a modified CTAB DNA extraction procedure (Doyle and Doyle 1990). DNA pellets were diluted with $300 \mu \mathrm{L}$ of TE (10 mM Tris, $0.1 \mathrm{mM}$ EDTA, $\mathrm{pH} 7.4)$, and their concentrations were measured with a semi-automated microplate reader, PowerWave HT (BIO-TEK
Instruments, Inc., Winooski, VT, USA), and $10 \mathrm{ng} \mathrm{\mu L}^{-1}$ DNA templates for PCR amplifications were made using double distilled water.

Thirty-four combinations of 13-forward and 16-reverse SRAP primers as listed by $\mathrm{Li}$ and Quiros (2001); 13 peroxidase gene polymorphism (POGP) primer combinations reported to work in a number of grasses as listed in Gulsen et al. (2007); 8 ISSR primers [(GAA) ${ }_{6}$, $\mathrm{HVH}(\mathrm{CA})_{7},(\mathrm{GT})_{8} \mathrm{Y}, \mathrm{BDB}(\mathrm{CA})_{7} \mathrm{C}, \mathrm{DBDA}(\mathrm{CA})_{7},(\mathrm{GACA})_{4^{\prime}}$ $\operatorname{VHV}(\mathrm{GT})_{7}$, and $(\mathrm{GA})_{8} \mathrm{Y}$, as described in Fang and Roose (1997); and 10 RAPD primers (Operon I01, I03, I08, I11, I16, M05, M16, F10, W15, and W19) were used in this study. These primers listed above were selected based on a preliminary screening of DNA bulks from 10 randomly selected accessions to identify primers yielding the highest number and consistency of bands. PCR reactions and cycling parameters were the same as reported in $\mathrm{Li}$ and Quiros (2001); Gulsen et al. (2007); Fang and Roose (1997). PCR products were separated on a $2.5 \%$ agarose gel at $90 \mathrm{v}$ for $4 \mathrm{~h}$, and visualized under UV light.

\section{Data analysis}

Each marker band was visually scored as present (1) or absent (0), and data were analyzed with the Numerical Taxonomy Multivariate Analysis System (NTSYS-pc) version 2.1 software package (Exeter Software, Setauket, New York, USA) (Rohlf 1993). A genetic similarity (GS) matrix was constructed based on simple matching coef- 
Table 1. Mean nuclear DNA contents, ploidy levels as measured by flow cytometry, and collection region of the 182 Cynodon accessions into the six provinces and five ploidy levels

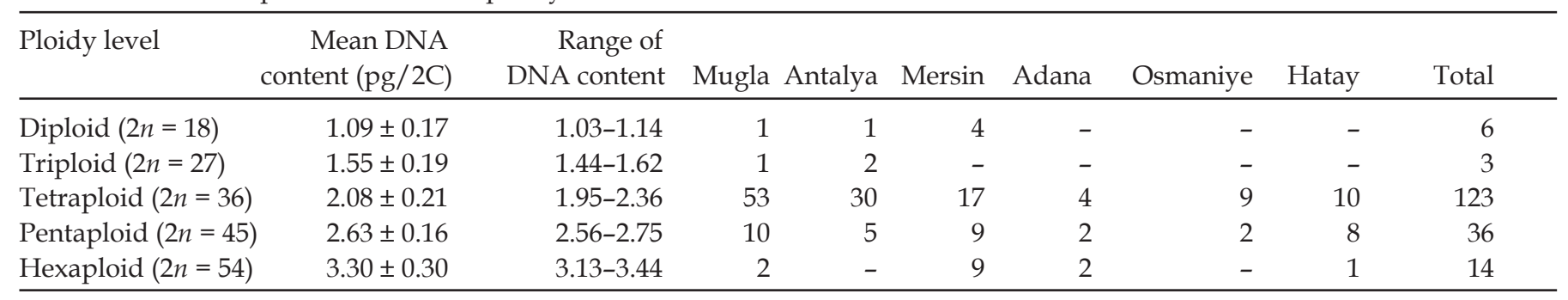

The six provinces span about 1,000 km west to east direction in southern Turkey. Ploidy levels of outgroups as follows: C. transvaalensis was diploid; Tifway was triploid; and Blackjack, Mohawk, SWI-1044, SWI-1045, Princess, Riviera Sultan and NuMex Sahara were tetraploid.

ficients within the SIMQUAL module calculated as $m / n$ ( $m$ total number of matching bands, $n$ total number of bands scored for a particular pair of genotypes). The GS matrix was used to construct a dendogram using the unweighted pair group method arithmetic average (UPGMA) to determine genetic relationships among the genotypes studied. To provide a "goodness-of-fit" test for the GS matrix to cluster analysis, first, COPH module was used to transform the tree matrix to a matrix of ultrametric similarities (a matrix of similarities implied by the cluster analysis) and then, MXCOMP module was used to compare this ultrametric similarities to the similarity matrix produced. The MXCOMP module was also used to calculate correlation coefficients between each pair of similarity matrices produced in the four marker systems. This procedure is called the Mantel test and indicates whether two marker systems produce similar clustering patterns (Mantel 1967).

Regression analysis using PROC REG (SAS, Cary, NC, USA) was used to investigate linear, quadratic, and cubic associations between ploidy level and band frequency in the Cynodon accessions, considering correlation coefficient, $r$, and adjusted correlation coefficient, $r^{2}$, values and significance of variables in each model. The allele frequency for each locus scored on the 192 genotypes was calculated as: $a / a+b$, where $a$ is the number of present alleles (1), $b$ is the number of absent alleles (0), excluding missing values.

Frequency of rare present alleles $(<5 \%$ and $<10 \%$ level) for each marker system was calculated as: $Q=a / b$, where $a$ is the number of rare (5 or 10\%) present alleles and $b$ is the total number of bands scored for a specific locus. The number of bands was detected based on the observed total number of bands in all genotypes. Polymorphism information content (PIC) values were calculated as: $\mathrm{PIC}=1-\mathrm{Pi}^{2}$.

The partitioning of molecular variance within and among ploidy levels was calculated by the AMOVA (Excoffier et al. 1992) in ARLEQUIN ver. 2.000 software
(Univ. of Geneva, Geneva, Switzerland) (Schneider et al. 2001). The AMOVA was also performed to estimate the amount of variation among regions, among provinces, and within provinces. Genotypes were grouped as western (Mugla and Antalya provinces), central (Mersin and Adana provinces), and eastern (Osmaniye and Hatay provinces) types based on their geographic locations (Figure 1). Three regions, eastern, western, and central, are geographically separated by the mountains. Euclidean distance matrices (total number of polymorphic bands for pair wise comparisons of individual plants) were used as data input for AMOVA. The number of permutations for significance testing was set at 10,000 for all analyses. The fixation index (FST), a measure of population differentiation calculated by ARLEQUIN, was used to estimate pair wise differences between populations for both ploidy and geographical distribution (Hudson et al. 1992).

\section{Results}

\section{Ploidy distribution}

Mean 2C nuclear DNA contents of the 182 Cynodon accessions collected from Turkey are presented in Table 1. A representative flow histogram for each ploidy level and its related mitotic metaphase chromosomes are shown in Figs. 2, 3, respectively. Based on their nuclear DNA content, the genotypes were grouped into 5 different ploidy levels as diploid, triploid, tetraploid, pentaploid, and hexaploid. The most prevalent $(68 \%)$ ploidy level is tetraploids. Unlike the Chinese and Korean Cynodon accessions, we determined diploid genotypes growing in Turkey naturally in addition to triploid, tetraploid, pentaploid and hexaploids (Wu et al. 2006; Kang et al. 2007). The ploidy distribution of the Cynodon accessions studied was positively skewed toward higher ploidy levels with a skew value of 2.8, which suggests that higher ploidy levels occur more frequently in nature. 


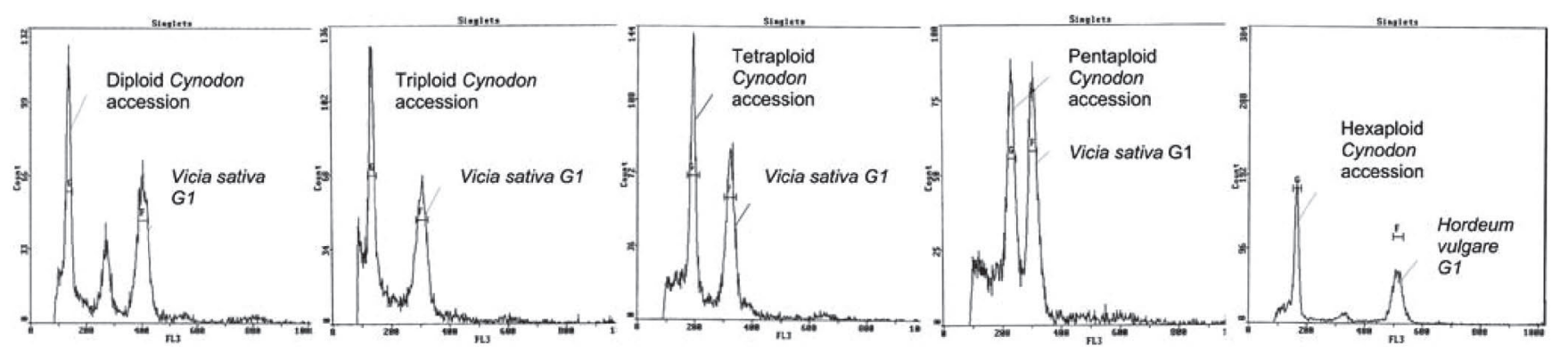

Figure 2. Relative positions of the G1 peaks of the Cynodon accessions and internal standards as follows: a) diploid, b) triploid, c) tetraploid, d) pentaploid, and e) hexaploid.
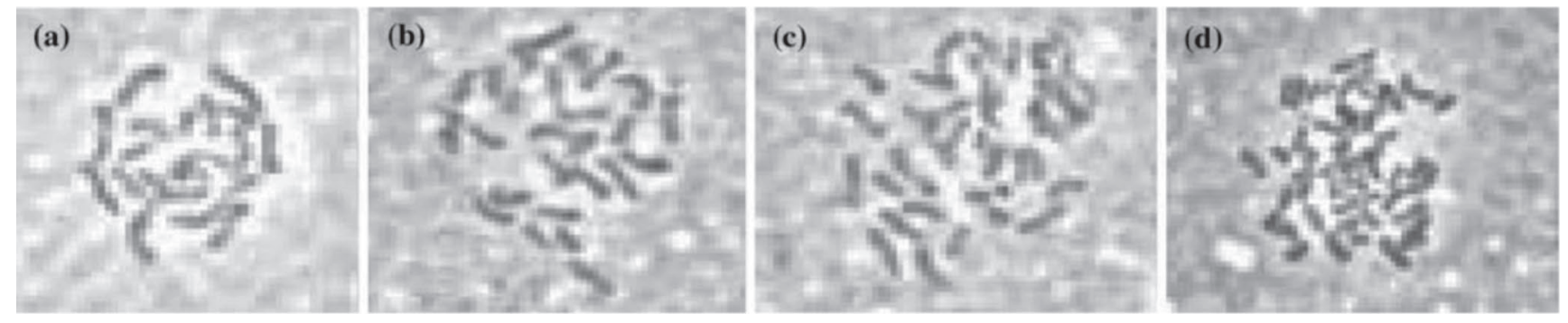

Figure 3. Pictures of mitotic metaphase chromosomes of the Cynodon accessions with different ploidy levels as follows: a) diploid $(2 n=18), \mathbf{b})$ triploid $(2 n=27), \mathbf{c})$ tetraploid $(2 n=36)$, and $\mathbf{d})$ hexaploid $(2 n=54)$. Note that there is no picture of pentaploid due to non-availability of dividing cells in root tips.

\section{Analysis of relationships between polyploidy and mo- lecular markers}

There were varying frequencies of present alleles in the five different ploidy levels observed among the bermudagrass accessions and cultivars studied. The diploids, triploids, tetraploids, pentaploids, and hexaploids had a mean frequency for the present bands of 0.36 , 0.47, 0.49, 0.52, and, 0.54, respectively (Figure 4). Based on combined data from all markers used, regression analysis indicated that quadratic association between ploidy level and band frequency was the most explanatory $(r=0.62 ; P<0.001)$, revealing that $38 \%$ of variation in band frequency was explained by ploidy level. Thus, the band frequency for a particular bermudagrass genotype with known ploidy level can be estimated with the following model:

$$
\mathrm{Pbf}=0.154+0.125 x-0.010 x^{2}
$$

where Pbf is present band frequency of an individual with known ploidy level and $x$ is its ploidy level. In example, the band frequency for the diploid accession 97 and pentaploid 98 were 0.40 and 0.52 , respectively. The diploid 148 and tetraploid 149, both collected from the same region, had band frequencies of 0.36 and 0.50 .

The four molecular marker systems differed in detecting correlation estimates between ploidy level and present band frequency (i.e. SRAP, POGP, ISSR, and RAPD, $r=0.43,0.33,0.44$, and 0.40 , respectively). A low

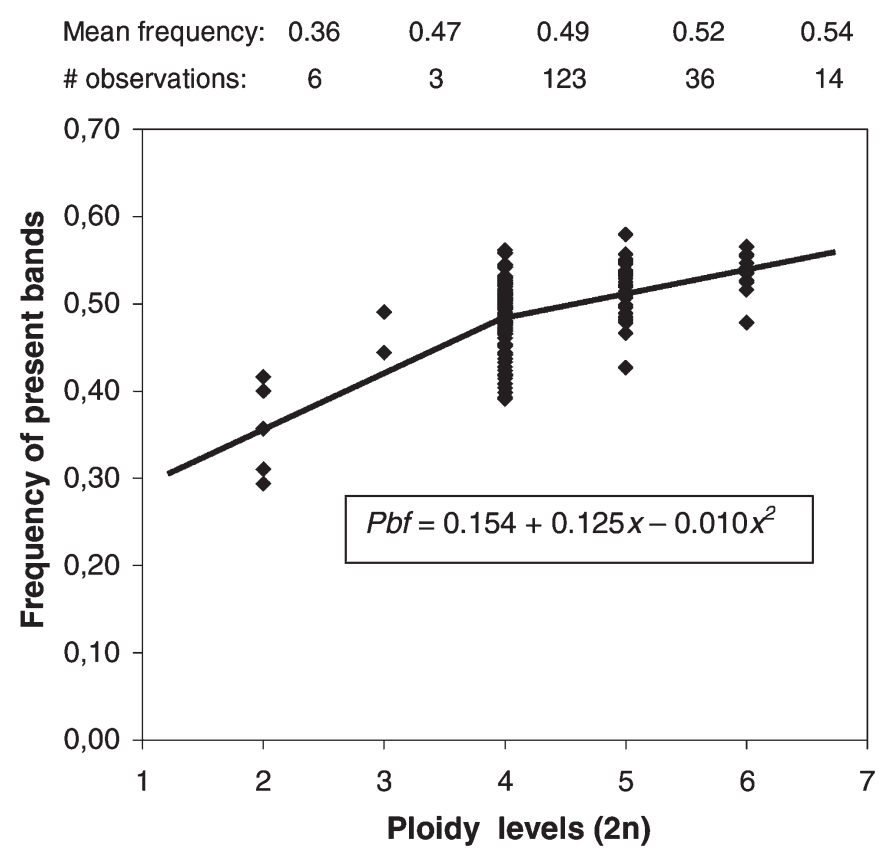

Figure 4. Distribution of ploidy levels and band frequency of the SRAP, POGP, ISSR, and RAPD markers in the Cynodon accessions, and the best fit quadratic line and the equation.

linear response $(r=0.33, P<0.01)$ was detected for POGP markers, similar to that reported by Duroux and Welinder (2003). Therefore, POGP markers could have a low level of polymorphism among the Turkish Cynodon accessions compared to the other three marker systems. 
Table 2. Analysis of molecular variance (AMOVA) for each ploidy level

\begin{tabular}{lrcc}
\hline Source of variation & $d f$ & $\begin{array}{c}\text { Sum of } \\
\text { squares }\end{array}$ & $\begin{array}{l}\text { Variation } \\
\text { percentage }\end{array}$ \\
\hline Among ploidy levels & 4 & 277 & 9 \\
Within ploidy levels & 177 & 3,901 & 91 \\
Total & 181 & 4,178 & \\
\hline
\end{tabular}

Significant at $5 \%$ level $P<0.05$

Table 3. Analysis of molecular variance (AMOVA) for each province and Mugla-Antalya (western) Adana-Mersin (central), and Osmaniye-Hatay (eastern) regions

\begin{tabular}{lrrc}
\hline Source of variation & $d f$ & $\begin{array}{r}\text { Sum of } \\
\text { squares }\end{array}$ & $\begin{array}{r}\text { Percentage of } \\
\text { variation }\end{array}$ \\
\hline Among regions & 2 & 131 & 1 \\
Within regions & 3 & 148 & 5 \\
Within provinces & 177 & 3,480 & 94 \\
Total & 181 & 3,760 & \\
\hline
\end{tabular}

Significant at $5 \%$ level $P<0.05$

Table 4. Population corrected average pair wise differences for the six provinces based on the 407 SRAP, POGP, ISSR, and RAPD markers

\begin{tabular}{rrrrrr}
\hline & 1 & 2 & 3 & 4 & 5 \\
\hline 2 & 3.18 & - & & & \\
3 & 2.45 & 2.10 & & & \\
4 & 3.41 & 3.81 & 1.57 & & \\
5 & 4.10 & 3.57 & 1.80 & 1.71 & \\
6 & 3.17 & 4.05 & 1.26 & 1.20 & 0.96 \\
\hline
\end{tabular}

It was calculated as follows: $(\mathrm{PiX} Y-(\mathrm{PiX}+\mathrm{Pi} Y) / 2)$, where $\mathrm{PiXY}$ $=$ average number of pair wise differences between populations, and $P i Y=$ average number of pair wise differences within population. The positions of provinces are located from west to east and their names are abbreviated as: 1, Mugla; 2, Antalya; 3, Mersin; 4, Adana; 5, Osmaniye; 6, Hatay.

\section{Relationships and partitioning genetic variation into geographic locations and ploidy levels}

The AMOVA showed that $91 \%$ of the total variation resides within ploidy level (Table 2). The FST values, an indication of population differentiation to estimate pair wise allelic differences between ploidy levels, were lowest between adjacent ploidy levels and highest between distant ploidy levels (data not shown). The AMOVA depicted a similar pattern for partitioning diversity into geographic distribution (Table 3). Within province variation contributed $94 \%$ of the total variation, while within region (i.e. western, central, and eastern) accounted for $5 \%$ of the variation. The FST values also were highest between distant regions (i.e. between Mugla province of western Turkey and Osmaniye province of eastern Turkey, and between Antalya province of Central and Hatay province of eastern Turkey (Table 4). Similarly, the UPGMA method did not indicate a strong association between GS and geographic origin (Figure 5).

The cophenetic correlation (Mantel test) between ultrametric similarities of the tree and the GS matrix was found to be high $(r=0.96)$, which suggests that the cluster analysis performed for this data strongly represents the GS matrix (Figure 5). Based on the GS coefficients produced with 407 markers, the UPGMA clustered the 182 accessions and 10 cultivars into three major groups with a mean similarity value of 0.50 . Group 1 had the largest number of genotypes (164), followed by Group 2 (23) and Group 3 (5). There was considerable genetic diversity, ranging from 0.50 to 0.98 , among the natural Cynodon accessions available to plant breeding programs as measured in this study.

The AMOVA revealed that the most of the variation (91\%) resided within ploidy level. Accordingly, the UPGMA dendogram showed weak ploidy-based groupings (Figure 5). Group 1 consists of six ploidy specific subgroups as shown in Figure 5. Subgroup 1-4 (4th group in Group 1) included 18 pentaploids that were collected on an area extending about $500 \mathrm{~km}$. Subgroup 1-2 included one sub-cluster that had six pentaploids $(66 \%)$ in very close proximity. This suggests that the part of the pentaploid genome was inherited from a distinct parent. The tetraploids placed in Subgroup 1-1 and 1-2, while hexaploids were in Subgroup 1-3 and 1-6. Subgroup 1-7 had five diploids in one of the subclusters, 97, 126, 127,128, and 148 that had distant geographic origins spanning about $600 \mathrm{~km}$. In turn, group 2 , included the tetraploids, pentaploids, and hexaploids. Subgroup 1-3 also included mixtures of the tetraploids, pentaploids, and hexaploids. Overall, these results were consistent with $\mathrm{Wu}$ et al. (2006), which found slight ploidy-based groupings among the 119 Chinese Cynodon accessions. Another meaningful cluster, Group 2,

Figure 5 (opposite). Unweighted pair group method arithmetic average (UPGMA) dendogram with similarity coefficients for 192 Cynodon accessions based on analysis of 407 markers as amplified with SRAP, POGP, ISSR, and RAPD primers. Ploidy levels are indicated after the first number separated by a dash (-). i. e. For accession 1-2, ' 1 ' stands for the accession number and ' 2 ' indicates its ploidy level. For unavailable data points, '?' is used. Given numbers of outgroups used in this study were as follows: Blackjack, 193; Mohawk, 194; Sultan, 195; NuMex Sahara, 196; SWI-1044, 197; SWI-1045 (Contessa), 198; Princess 77, 199; Riviera, 200; C. transvaalensis, 201; and Tifway, 202. Group and subgroup numbers were indicated next to the continuous line, in which the first digit stands for group number, and the second digit is for subgroup number. Note that the genotypes with a higher similarity value than 0.88 were joined for easy visualization of the figure; therefore upper similarity coefficient appears 0.88 instead of 0.9 . 


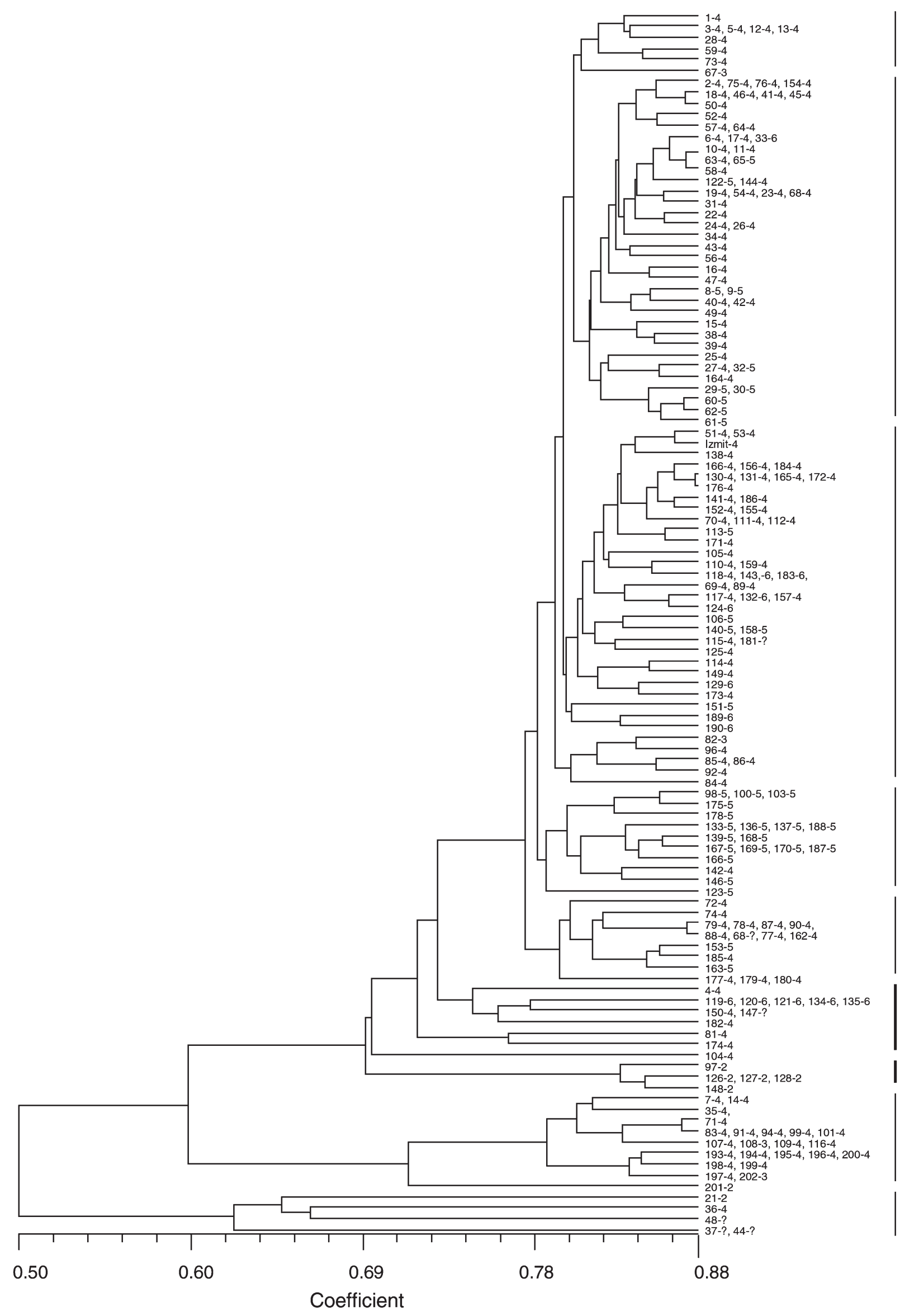

1-1

1-2

1-3 
included nine known cultivars and 13 accessions along with the experimental line of $C$. transvaalensis, a major progenitor of modern triploid turf cultivars and native to South Africa (Figure 5). The dendogram indicates a level of $C$. transvaalensis contribution to genome of the modern cultivars and its similarity to Turkish natural Cynodon populations collected from undisturbed natural sites and ruins. Commercial bermudagrass cultivars represented only one-third of the available genetic variation. The findings were significant from the view of adaptation and evolution of this warm season turfgrass.

\section{Comparison of the four marker systems in Cynodon ge- netic analyses}

In this study, the combined analysis of SRAP, POGP, ISSR, and RAPD markers gave genetic distance estimates that averaged 0.73, and ranged from 0.50 to 0.98 (Figure 5). Correlation coefficients of so-called Mantel test among the GS similarity matrices produced with SRAP, POGP, and ISSR markers were similar $(r=0.85,0.86$, and 0.87 , respectively). However, correlation between RAPD and the other markers was low (0.71). Garcia et al. (2004) found similar results in maize (Zea mays L.).

The four markers systems differed in detecting rare alleles. POGP markers (22\%) more frequently produced rare alleles (occurring less than $10 \%$ followed by SRAP $(17 \%)$, ISSR (15\%), and RAPD (14\%). For rare alleles occurring less than $5 \%$, the order was POGP (15\%), ISSR (8\%), SRAP (8\%), and RAPD (4\%).

The 34 SRAP, and 13 POGP primer combinations, 8 ISSR, and 8 RAPD primers produced 185, 85, 61, and 85 polymorphic markers, respectively, totaling 407 markers from the 192 genotypes. All of the bands scored were polymorphic. On average, SRAPs, POGPs, ISSRs, and RAPDs produced 5.4, 6.5, 7.6, and 10.6 scorable bands per amplification, respectively. The average PIC of the 63 amplifications was 0.52 with decreasing levels of 0.58 (RAPD), 0.56 (POGP), 0.51 (SRAP), and 0.41 (ISSR). Hou et al. (2005) found similar PIC results in barley (Hordeum vulgare ssp. vulgare).

\section{Discussion}

Observed DNA contents of polyploid Cynodon accessions are almost equal to expected DNA content of polyploids, which supports the results reported for autotetraploid A. thaliana (Ozkan et al. 2006). Nuclear DNA contents of triploid, tetraploid, pentaploid, and hexaploids are approximately 1.5, 2, 2.5, and 3 times larger, respectively, than the DNA content of diploids except for hexaploid Turkish populations. Hexaploid Turkish ecotypes had a higher nuclear DNA content than ex- pected. It may be due to different internal standard. We had to use diploid barley cultivar as internal standard for hexaploid ecotypes since their G1 peak overlapped with G1 peak of $V$. sativa that we have used for other ploidy levels. Error would be larger if we used barley as internal standard for all the ploidy levels since it has very large genome compared to bermudagrass ecotypes. In a previous study on perennial grasses of Triticeae, Vogel et al. (1999) demonstrated that gain or loss of nuclear DNA content occurred during the evolution of the perennial Triticeae as a part of the species development process. A nuclear DNA content reduction also occurred in natural Bromus spp. populations (Tuna et al. 2001), and natural and synthetic populations of genera Aegilops and Triticum (Ozkan et al. 2003). However, unlike allopolyploids, no DNA loss was observed in autotetraploid Arabidopsis thaliana (L.) Heyhn during polyploidization (Ozkan et al. 2006). The results of nuclear DNA content analysis on Turkish, Korean and Chinese bermudagrass ecotypes indicate a little or no reduction in the nuclear DNA content during polyploidization.

Unlike the Chinese and Korean Cynodon accessions, the Turkish Cynodon accessions included diploid genotypes in addition to triploid, tetraploid, pentaploid and hexaploids. This might support Harlan and de Wet (1969)' statement that an area from West Pakistan to Turkey is the center of evolutionary activity for the genus Cynodon L. C. Rich.

Regression analysis carried out to detect linear, quadratic, and cubic associations between ploidy level and band frequency indicated that quadratic association between ploidy level and band frequency was the most explanatory $(r=0.62 ; P<0.001)$, and revealed that $38 \%$ of variation in band frequency was explained by ploidy level. The ploidy levels of Cynodon accessions are generally morphologically indistinguishable, which is also the case with buffalograss (Shearman et al. 2004). It is likely that extra copies of homologous chromosomes at higher ploidy levels do not influence the morphological structures expressed for adaptation to diverse environments. Wendel (2000) and Leitch and Leitch (2008) suggested that increased ploidy levels likely result in increased diversity, which gives plant species significant advantages for adaptation to variable environments. Cynodon accessions, like buffalograss, also demonstrated a similar relationship between ploidy and allele frequency (Gulsen et al. 2005). The results observed for these two species give a strong indication that a similar evolutionary pathway might apply to both species with respect to polyploidization. Johnson et al. (2001) found higher adaptability in hexaploid buffalograsses, which could be explained by gene diversification as suggested by Wendel (2000). We found a positive skew value (2.8) toward higher ploidy 
levels, which suggests that elevated ploidy levels occur more frequently in nature. This is consistent with finding supports the idea of higher fitness potential of polyploids in nature. The second significant finding is rapid increase in band number observed in tetraploids (0.49) relative to that of diploids (0.36) and hexaploids (0.54). This might be related to contribution of a more distinct parent during tetraploidization of the genus Cynodon.

Although correlation coefficients calculated in this study are low, significance of level of correlation coefficient depends on context (Ott 1993). This low correlation value is not surprising because polyploidization and DNA diversification may not have the same pace. Diversification would be would be progressively affected by environmental constrains and epigenetic interactions whereas polyploidization is a sudden event.

Budak et al. (2005) reported significant but lower correlation coefficients $(r=40)$ for ploidy level and band numbers in buffalograss. In this study, we improved calculation method by eliminating missing genotypes due to amplification or gel fragmentation errors. This calculation method significantly influenced correlation estimates when missing bands for each locus were scored. The linear correlation coefficient between ploidy level and band frequency was $r=56$, and when the number of alleles was used, the correlation coefficient decreased to $r=0.40$ for the same data set.

We tried to estimate whether molecular diversity differ in six ploidy levels, three geographic regions, and six provinces using AMOVA, UPGMA, and FST procedures, and found that within ploidy level, geographic region, and province represent the most nuclear genome variation, and that there are weak or no ploidy or geography-based groupings. Overall, results were consistent with $\mathrm{Wu}$ et al. (2006), which also found slight ploidybased groupings among the 119 Chinese Cynodon accessions. Huff et al. (1998) and Gulsen et al. (2005) also found no association between geographic origin and genetic variation in little bluestem (Schizachyrium scoparium) and buffalograss, respectively. The lack of strong association between geographic origin and genetic variation may be attributed to outcrossing and self-incompatibility and lack of geographic isolation due to exchange of genetic material through human activities. The genetic diversity was relatively high, ranging from 0.50 to 0.98 , which was similar to that observed in Chinese Cynodon accessions (Wu et al. 2006) and USA forage type bermudagrasses (Karaca et al. 2002).

The UPGMA analysis resulted in few meaningful clusters. The seeded-type commercial cultivars (Blackjack, Mohawk, Sultan, NuMex Sahara, SWI-1044, SWI1045 (Contessa), Princess 77, Riviera, and Tifway numbered as 193, 194, 195, 196, 197, 198, 199, 200, and 202, respectively) showed a narrow genetic variation and clustered together with the high GS values $(>0.85)$. There was considerable genetic diversity, ranging from 0.50 to 0.98 , among the Turkish Cynodon accessions available to plant breeding programs as measured in this study. But, undesirable characters are very likely as in the other crop plants, therefore, should be kept in mind (Baenziger et al. 2006). On the other hand, broadening genetic base of commercial cultivars using diversity observed among the Turkish Cynodon accessions may bring more adaptive commercial cultivars.

Group 2, included nine known cultivars and 13 accessions along with the experimental line of $C$. transvaalensis, a major progenitor of modern triploid turf cultivars (Figure 5). The dendogram indicates a level of C. transvaalensis contribution to genome of the modern cultivars and natural populations. Commercial bermudagrass cultivars represented only one-third of the available genetic variation. The findings were significant from the view of breeding, adaptation, and evolution of this warm season turfgrass.

Rare alleles caused by selection pressure and genetic drift may have a(n) advantage or disadvantage depending on aim of a study (Remington et al. 2001). Detection rate of rare alleles by molecular marker systems may differ due to their priming sites. In this study, the four markers systems differed in detecting rare alleles. POGP markers more frequently produced rare alleles occurring less than 5 and 10\% compared to the SRAP, ISSR, and RAPD markers. This indicates that peroxidase gene evolution is more recent and an ongoing process, or unique peroxidase alleles are being created in bermudagrass genotypes with different ploidy levels. Rare alleles are desirable in cultivar identification and diversity studies, but undesirable in marker-trait association or association mapping studies. They may cause false positive associations in detecting markers linked to major plant traits such as yield and disease resistance. Therefore, markers with rare occurrence are discarded in association studies.

\section{Conclusion}

This was the first comprehensive report on the Cynodon accessions collected from southern Turkey. All ploidy levels from diploids to hexaploids exist in native Turkish Cynodon populations. We found that increased ploidy levels strongly associated with higher band frequency $(r=0.62)$, and band frequency of an individual with known ploidy level can be estimated using the formula Pbf $=0.154+0.125 x-0.010 x^{2}$. As Wendel (2000) suggested, this response could be due to gain of new function, maintenance of original structure or function, and silencing point mutations. Genetic relationship anal- 
ysis, among the 192 Cynodon accessions and cultivars, and five ploidy levels based on the 407 nuclear genome markers used, indicated a weak grouping pattern (i.e. $>0.70$ ) for ploidy levels as observed in Group 1, which may indicates a possible indication of contribution of different genomes in Cynodon species. The GS matrices produced from the SRAP, POGP, and ISSR marker systems had similar correlation values $(r=0.86)$, but RAPD markers had a correlation coefficient of $r=0.71$ with the other three markers systems, suggesting the relatively high efficiency of combined analysis with the different marker systems. The four marker systems also differed in detecting rare alleles. These results will contribute to our understanding of the potential relationships among molecular markers, ploidy levels, and geographic distribution of genus Cynodon. Currently, the genotypes used in this study are under investigation for many agronomical traits such as turf quality, and drought tolerance. The variation present in the Turkish Cynodon accessions may have significant contribution in C. dactylon breeding programs for various uses such as turf, forage, soil stabilization, and remediation, as well as our understanding evolution of this warm season grass.

Acknowledgments - This research was supported by the Scientific and Technical Research Council of Turkey under the project code TUBITAK TOVAG: 105 O 586.

\section{References}

Baenziger PS, Russell WK, Graef GL, Campbell BT (2006) Improving lives: 50 years of crop breeding, genetics, and cytology. Crop Sci 46:2230-2244

Budak H, Shearman RC, Gulsen O, Dweikat I (2005) Understanding ploidy complex and geographic origin of the buffalograss genome using cytoplasmic and nuclear marker systems. Theor Appl Genet 111:1545-1552

Burton GW (1947) Breeding bermudagrass for the southeastern United States. Agron J 39:551-569

Burton GW, Hart RH (1967) Use of self-incompatibility to produce commercial seed propagated F1 bermudagrass hybrids. Crop Sci 7:524-527

Caetano-Anolles G, Callahan LM, Williams PE, Weaver KR, Gresshoff PM (1995) DNA amplification fingerprinting analysis of bermudagrass (Cynodon): genetic relationships between species and interspecific crosses. Theor Appl Genet 91:228-235

Doyle JJ, Doyle JL (1990) Isolation of plant DNA from fresh tissue. Focus 12:13-15
Dubcovsky J, Dvorak J (2007) Genome plasticity a key factor in the success of polyploid wheat under domestication. Science 316:1862-1865

Duroux L, Welinder KG (2003) The peroxidase gene family in plants: a phylogenetic overview. J Mol Evol 57:397-407

Excoffier L, Smouse PE, Quattro JM (1992) Analysis of molecular variance inferred from metric distance among DNA haplotypes: application to human mitochondrial DNA restriction data. Genetics 131:479-491

Fang DQ, Roose ML (1997) Identification of closely related Citrus cultivars with inter-simple sequence repeat markers. Theor Appl Genet 95:408-417

Garcia AF, Benchimol LL, Barbosa AMM, Geraldi IO, Souza CL Jr, De Souza AP (2004) Comparison of RAPD, RFLP, AFLP and SSR markers for diversity studies in tropical maize inbred lines. Genet Mol Biol 27:579-588

Gulsen O, Shearman RC, Vogel KP, Lee DJ, Baenziger PS, Heng-Moss TM, Budak H (2005) Nuclear genome diversity and relationships among naturally occurring buffalograss genotypes determined by sequence-related amplified polymorphism. HortScience 40:537-541

Gulsen O, Shearman RC, Heng-Moss TM, Mutlu N, Lee DJ, Sarath G (2007) Peroxidase gene polymorphism in buffalograss and other Grasses. Crop Sci 47:767-772

Harlan JR, De Wet JMJ (1969) Sources of variation in Cynodon dactylon (L.) Pers. Crop Sci 9:774-778

Harlan JR, De Wet JMJ, Huffine WW, Deakin JR (1970) A guide to the species of Cynodon (Gramineae). Bull B-673. Oklahoma Agric Exp Stat, Stillwater

Hou YC, Yan ZH, Wei YM, Zheng YL (2005) Genetic diversity in barley from west China based on RAPD and ISSR analysis. Barley Genet Newsl 35:9-22

Hudson RR, Hudson M, Maddison WP (1992) Estimation of levels of gene flow from DNA sequence data. Genetics 132:583-589

Huff DR, Quinn JA, Higgins B, Palazzo AJ (1998) Random amplified polymorphic DNA (RAPD) variation among native little bluestem [Schizachyrium scoparium (Michx.) Nash] populations from sites of high and low fertility in forest and grassland biomes. Mol Ecol 7:1591-1597

Johnson PG, Kenworthy KE, Auld DL, Riordan TP (2001) Distribution of buffalograss polyploid variation in the southern Great Plains. Crop Sci 41:909-913

Kang SY, Lee GJ, Lim KB, Lee HJ, Park IS, Chung SJ, Kim JB, Kim DS, Rhee HK (2007) Genetic diversity among Korean bermudagrass (Cynodon spp) ecotypes characterized by morphological, cytological and molecular approach. Mol Cells 25:163-171

Karaca M, Saha S, Zipf A, Jenkins JN, Lang DJ (2002) Genetic diversity among forage bermudagrass (Cynodon spp.): evidence from chloroplast and nuclear DNA fingerprinting. Crop Sci 42:2118-2127

Leitch AR, Leitch IJ (2008) Genomic plasticity and the diversity of polyploid Plants. Science 320:481-483 
Li G, Quiros CF (2001) Sequence-related amplified polymorphism (SRAP) a new marker system based on a simple PCR reaction: its application to mapping and gene tagging in Brassica. Theor Appl Genet 103:455-461

Mantel NA (1967) The detection of disease clustering and a generalized regression approach. Cancer Res 27:209-220

Ott RL (1993) Analyzing data: regression methods. In: An introduction to statistical methods and data analysis. Duxbury Press, CA, pp 435-490

Ozkan H, Tuna M, Arumuganathan K (2003) Non additive changes in genome size during allopolyploidization in the wheat (Aegilops-Triticum) group. Heredity 94:260-264

Ozkan H, Tuna M, Galbraith DW (2006) No DNA loss in autotetraploids of Arabidopsis thaliana. Plant Breed 125:288-291

Remington DL, Thornsberry JM, Matsuoka Y, Wilson LM, Whit SR, Doebley J, Kresovich S, Goodman MM, Buckler ES (2001) Structure of linkage disequilibrium and phenotypic associations in the maize genome. Proc Natl Acad Sci 98:11479-11484

Renvoize SA, Clayton WD (eds) (1992) Classification and evolution of the grasses. In: Grass evolution and domestication. Cambridge University Press, New York, pp 3-37

Rohlf FJ (1993) NTSYS-PC, numerical taxonomy and multivariate analysis system. Version 1.8. Exeter Software, Setauket

Schneider S, Roessli D, Excoffier L (2001) Arlequin: a software for population genetics data analysis. Version 2.000. Genetics and Biometry Lab. Department of Anthropology, University of Geneva, Geneva

Shearman RC, Riordan TP, Johnson PG (2004) Buffalograss. In: Moser L (ed) Warm season grasses. Agronomy monograph 45. Amer Soc Agron, Madison, pp 1003-1026

Song K, Lu P, Tang K, Osborn TC (1995) Rapid genome change in synthetic polyploids of Brassica and its implications for polyploid evolution. Proc Natl Acad Sci 92:7719-7723
Taliaferro CM (2003) Bermudagrass (Cynodon (L.) Rich). In: Casler MD, Duncan RR (eds) Turfgrass biology, genetics, and breeding. John Wiley and Sons, Inc, New Jersey, pp 235-257

Tuna M, Vogel KP, Arumuganathan K, Gill KS (2001) DNA content and ploidy determination of bromegrass germplasm accessions by flow cytometry. Crop Sci 41:1629-1634

Vogel KP, Arumuganathan K, Jensen KB (1999) Nuclear DNA conent of Prennial grasses of the Triticeae. Crop Sci 39:661-667

Vos P, Hogers R, Bleeker M, Reijans M, Van de Lee T, Hornes M, Frijters A, Pot J, Peleman J, Kuiper J, Zabeau M (1995) AFLP: a new technique for DNA fingerprinting. Nuc Acids Res 23:4407-4414

Wendel JW (2000) Genome evolution in Polyploids. Plant Mol Biol 42:225-249

Wu YQ, Taliaferro CM, Bai GH, Anderson MP (2005) Genetic diversity of Cynodon transvaalensis Burtt-Davy and its relatedness to hexaploid C. dactylon (L.) Pers. As indicated by AFLP markers. Crop Sci 45:848-853

Wu YQ, Taliaferro CM, Martin DL, Anderson CA, Anderson MP (2006) Genetic analyses of Chinese Cynodon accession by flow cytometry and AFLP markers. Crop Sci 46:917-926

Wu YQ, Taliaferro CM, Martin DL, Anderson CA, Anderson MP (2007) Genetic variability and relationships for adaptive, morphological, and biomass traits. Crop Sci 47:1985-1994

Zeven AC (1979) Polyploidy and domestication: The origin and survival of polyploids in cytotype mixtures. In: Lewis WH (ed) Polyploidy, biological relevance. Plenum Press, New York, pp 385-408

Zhang LH, Ozias-Akins P, Kochert G, Kresovich S, Dean R, Hanna W (1999) Differentiation of bermudagrass (Cynodon spp.) genotypes by AFLP analyses. Theor Appl Genet 98:895-902 